\title{
Attitude towards suicide prevention among accredited social health activists (ASHAs): A study from rural part of Karnataka
}

\author{
Anil Kumar Buruganahalli Nagendrappa ${ }^{1, *}$, Sushma Rayappa ${ }^{2}$ \\ ${ }^{\mathbf{1}}$ Associate Professor, ${ }^{2}$ Senior Resident, Dept. of Psychiatry, ${ }^{\mathbf{1}}$ Shridevi Institute of Medical Sciences and Research Hospital, Tumkur, \\ Karnataka, ${ }^{2}$ Mysore Medical College and Research Institute, Mysore, Karnataka, India
}

*Corresponding Author: Anil Kumar Buruganahalli Nagendrappa

Email: anilkbn23@gmail.com

\begin{abstract}
Introduction: Suicide is an increasingly important public health issue. Considering the shortage of mental health professionals in India, there is a need to integrate grass root health professionals in efforts at suicide prevention. Successful suicide prevention depends on health professionals' awareness about suicide and attitude toward suicide attempters.

Aim: This study was aimed to assess the attitude of Accredited Social Health Activists (ASHAs) towards suicide prevention.

Materials and Methods: Data was collected from 500 ASHAs working in 10 taluks of Tumkur district, Karnataka using attitude towards suicide prevention scale. Study design was cross- sectional.

Results: All of them were females with mean age of 34.9 years ( $\mathrm{SD}= \pm 5.46)$. Majority of them (97.2\%) had studied above secondary education ( $8^{\text {th }}$ class onwards). $80.4 \%$ of them had working experience of more than 3 years as health professionals. None of them had previous exposure to suicide prevention programs or workshops. $40 \%$ of them expressed that they are not comfortable in assessing person for suicide risk and 51\% considered working with suicidal patients is not rewarding. $45 \%$ ASHAs considered suicide prevention is not their responsibility and $49 \%$ were of the opinion that there is little an individual can do to prevent it. ASHAs who have studied pre- university and above expressed more positive attitude.

Conclusions: Less than half of the ASHAs had positive attitude toward working with suicidal patients. Hence, there is strong need to organize more educational and training programs on suicide prevention so that these grass root health professionals could be more equipped and trained to manage suicidal patients.
\end{abstract}

Keywords: Accredited social health activists, Health professional, Attitudes, Suicide, Suicide prevention.

\section{Introduction}

Suicide is an increasingly important public health issue: from 1990 to 2010 the number of global suicides increased by $32 \% .^{1}$ Similar to global trends, India has also witnessed significant increase in suicide in last three decades. The number of suicides in the country during the decade (2005$2015)$ have recorded an increase of $17.3 \%(1,33,623$ in 2015 from 1,13,914 in 2005). Eighty-four percent of global suicides occur in low and middle-income countries (LMICs); India and China alone account for $49 \%$ of global suicides. ${ }^{2}$

Suicide is a multifaceted problem resulting from a complex interaction of biological, genetic, psychological, social, cultural and environmental factors. Suicide prevention being a tough task needs the active involvement of different health professionals, educators, social agencies, governments, legislators, social communicators, law enforcers, families and communities. ${ }^{3}$ Appropriate dissemination of information and awareness-raising at all levels are essential elements in the success of suicide prevention.

In view of providing equitable, affordable and quality health care to the rural population, especially the vulnerable groups, Government of India launched the National Rural Health Mission (NRHM) in 2005 and one of the key components of this is to provide every village in the country with a trained female community health activist (ASHA or Accredited Social Health Activist). Selected from the village itself, the ASHA will be trained to work as an interface between the community and the public health system. She would be a promoter of good health practices. ASHA will be a health activist in the community who will create awareness on health and its social determinants and mobilize the community towards local health planning and increased utilization and accountability of the existing health services. ${ }^{4}$ Empowering ASHAs to identify, assess, manage and refer the suicidal person in the community is an important step in suicide prevention. In this regard, suicide prevention skills and awareness among ASHAs are of paramount importance in achieving successful prevention outcomes.

Since NRHM launch there are no studies from India to assess the attitude of ASHAs towards suicide prevention which is of paramount importance in achieving successful suicide prevention. Hence, this study was aimed to assess the attitude of ASHAs toward suicide prevention.

\section{Materials and Methods}

Tumkur district in Karnataka state, India has 10 taluks. All ASHAs working in 10 taluks were called for a meeting. They were explained about the aim of the study. ASHAs who were willing to participate in the study were enrolled and subsequently written informed consent was taken. Sociodemographic profile sheet and attitude toward suicide prevention scale were distributed among them. They were asked to read the questionnaire first and ask in case of problem in understanding any question. After answering their queries, they were asked to fill the questionnaires. Study was approved by Tumkur District Health Officer and Shridevi Institute of Medical Sciences and Research Hospital Ethical Committee, Tumkur. 
Socio-demographic Profile Sheet: It includes demographic details along with the additional information about working experience as health professionals and attending any suicide prevention workshop.

Attitude Toward Suicide Prevention Scale: ${ }^{5}$ It is a 14 items, self-rated, 5-point Likert scale with good internal consistency (Cronbach's alpha $=0.77$ ) and high test-retest reliability. It has been used in several studies. ${ }^{6-9}$

\section{Statistical Analysis}

Frequencies with percentages were calculated for categorical variables and mean, standard deviation and median were calculated for continuous variables. Comparisons were done by using the $\mathrm{Chi}^{-}$square test, and $\mathrm{t}$-test. SPSS (Statistical Package for the Social Science) version 16.0 for Windows (Chicago, Illinois, USA) was used for analysis.

\section{Results}

Socio- Demographic Details: As shown in Table 1, total sample consisted of 500 ASHAs working in various taluks of Tumkur district. All of them were females with mean age of 34.9 years $(\mathrm{SD}= \pm 5.46)$. Majority of them were married $(99.6$ $\%)$, from Hindu religion $(99.8 \%)$ studied above secondary education ( $8^{\text {th }}$ class onwards) $(97.2 \%)$ and belonged to middle socioeconomic class $(95 \%) .80 .4 \%$ of them had working experience of more than 3 years as health professionals. None of them had previous exposure to suicide prevention programs or workshops. (Table 1)

Table 1: Socio-demographic profile

\begin{tabular}{|c|c|c|}
\hline Socio- demographic variable & Frequency/Mean & Percentage/SD \\
\hline Mean age at presentation (S.D.) & 34.9 & $\mathrm{SD}= \pm 5.46$ \\
\hline \multicolumn{3}{|l|}{ Age Group } \\
\hline - 20-30 Years & 124 & 24.8 \\
\hline - 31-40 Years & 323 & 64.6 \\
\hline - 41-50 Years & 53 & 10.6 \\
\hline \multicolumn{3}{|l|}{ Marital status } \\
\hline - $\quad$ Married & 498 & 99.6 \\
\hline - Unmarried & 2 & 0.4 \\
\hline \multicolumn{3}{|l|}{ Education } \\
\hline - $\quad$ Higher Primary Education & 14 & 2.8 \\
\hline - $\quad$ Secondary Education & 366 & 73.2 \\
\hline - $\quad$ PUC and Above & 120 & 24.0 \\
\hline \multicolumn{3}{|l|}{ Religion } \\
\hline - Hindu & 499 & 99.8 \\
\hline - $\quad$ Muslim & 1 & .2 \\
\hline \multicolumn{3}{|l|}{ Location } \\
\hline - Rural & 499 & 99.8 \\
\hline - Urban & 1 & 0.2 \\
\hline \multicolumn{3}{|l|}{ SES } \\
\hline - Lower Middle Class & 4 & 0.8 \\
\hline - $\quad$ Middle Class & 475 & 95.0 \\
\hline - $\quad$ Upper Middle Class & 21 & 4.2 \\
\hline \multicolumn{3}{|l|}{ Experience } \\
\hline - Less than 2 Years & 98 & 19.6 \\
\hline - 3-6 Years & 131 & 26.2 \\
\hline - $\quad>6$ Years & 271 & 54.2 \\
\hline
\end{tabular}

Attitude toward Suicide Prevention: As shown in Table 2, one third of ASHAs were not comfortable about assessing suicide risk, considered suicide prevention as not their responsibility and working with them as not rewarding. $44 \%$ of respondents' opined that the people who are serious about committing suicide don't tell anyone. Again one third considered unemployment and poverty to be the main causes of suicide, there is little that an individual can do to prevent it and if a person survives a suicide attempt, then this was a play for attention. $40 \%$ opined there is no way of knowing who is going to commit suicide and one third said significant proportion of suicides are not preventable. On the positive side, one third opined that if we make more funds available to the appropriate health services we can decrease the suicide rate. 
Table 2: ASHAs attitude about suicide prevention as per attitude towards suicide prevention scale

\begin{tabular}{|c|c|c|c|c|c|c|}
\hline Questionnaires & $\begin{array}{l}\text { Median } \\
\text { response }\end{array}$ & $\begin{array}{l}\text { Strongly } \\
\text { Disagree }\end{array}$ & Disagree & Uncertain & Agree & $\begin{array}{c}\text { Strongly } \\
\text { Agree }\end{array}$ \\
\hline $\begin{array}{l}\text { I resent being asked to } \\
\text { do more about suicide }\end{array}$ & Agree & $120(24 \%)$ & $125(25 \%)$ & $23(4.6 \%)$ & $180(36 \%)$ & $52(10.4 \%)$ \\
\hline $\begin{array}{l}\text { - Suicide prevention is } \\
\text { not my responsibility }\end{array}$ & Agree & $124(24.8 \%)$ & $107(21.4 \%)$ & $45(9 \%)$ & $151(32.2 \%)$ & $63(12.6 \%)$ \\
\hline $\begin{array}{l}\text { Making more funds } \\
\text { available to the } \\
\text { appropriate health } \\
\text { services would make no } \\
\text { difference to the suicide } \\
\text { rate }\end{array}$ & Disagree & $129(25.8 \%)$ & $158(31.6 \%)$ & $77(15.4 \%)$ & $99(19.8 \%)$ & $37(7.4 \%)$ \\
\hline $\begin{array}{l}\text { Working with suicidal } \\
\text { patients is rewarding }\end{array}$ & Disagree & $102(20.4 \%)$ & $155(31 \%)$ & $86(17.2 \%)$ & $110(22 \%)$ & $47(9.4 \%)$ \\
\hline $\begin{array}{l}\text { If people are serious } \\
\text { about committing } \\
\text { suicide they don't tell } \\
\text { anyone }\end{array}$ & $\begin{array}{l}\text { Strongly } \\
\text { Agree }\end{array}$ & $113(22.6 \%)$ & $15(3 \%)$ & $35(7 \%)$ & $111(23 \%)$ & $222(44.4 \%)$ \\
\hline $\begin{array}{l}\text { I feel defensive when } \\
\text { people offer advice } \\
\text { about suicide prevention }\end{array}$ & Uncertain & $120(24 \%)$ & $73(14.6 \%)$ & $168(33.6 \%)$ & $103(20.6 \%)$ & $36(7.2 \%)$ \\
\hline $\begin{array}{l}\text { It is easy for people not } \\
\text { involved in clinical } \\
\text { practice to make } \\
\text { judgments about suicide } \\
\text { prevention }\end{array}$ & Agree & $98(19.6 \%)$ & $124(24.8 \%)$ & $75(15 \%)$ & $166(33.2 \%)$ & $37(7.4 \%)$ \\
\hline $\begin{array}{l}\text { If a person survives a } \\
\text { suicide attempt, then } \\
\text { this was a play for } \\
\text { attention }\end{array}$ & Agree & $121(24.2 \%)$ & $101(20.2)$ & $70(14 \%)$ & $160(32 \%)$ & $48(9.6 \%)$ \\
\hline $\begin{array}{l}\text { People have the right to } \\
\text { take their own lives }\end{array}$ & $\begin{array}{l}\text { Strongly } \\
\text { Disagree }\end{array}$ & $143(28.6 \%)$ & $95(19 \%)$ & $60(12 \%)$ & $115(23 \%)$ & $87(17.4 \%)$ \\
\hline $\begin{array}{l}\text { Since unemployment } \\
\text { and poverty are the } \\
\text { main causes of suicide, } \\
\text { there is little that an } \\
\text { individual can do to } \\
\text { prevent it }\end{array}$ & Agree & $153(30.6 \%)$ & $93(18.6 \%)$ & $65(13 \%)$ & $170(34 \%)$ & $19(3.8 \%)$ \\
\hline $\begin{array}{l}\text { I don't feel comfortable } \\
\text { assessing someone for } \\
\text { suicide risk. }\end{array}$ & Agree & $97(19.4 \%)$ & $120(24 \%)$ & $83(16.6 \%)$ & $161(32.2 \%)$ & $39(7.8 \%)$ \\
\hline $\begin{array}{l}\text { Suicide prevention } \\
\text { measures are a drain on } \\
\text { resources, which would } \\
\text { be more useful } \\
\text { elsewhere }\end{array}$ & Uncertain & $107(21.4 \%)$ & $75(15 \%)$ & $167(33.4 \%)$ & $102(20.4 \%)$ & $49(9.8 \%)$ \\
\hline $\begin{array}{l}\text { There is no way of } \\
\text { knowing who is going } \\
\text { to commit suicide }\end{array}$ & Agree & $121(24.2 \%)$ & $96(19.2 \%)$ & $56(11.2 \%)$ & $201(40.2 \%)$ & $26(5.2 \%)$ \\
\hline $\begin{array}{l}\text { Significant proportion } \\
\text { of suicides are } \\
\text { preventable }\end{array}$ & Disagree & $108(21.6 \%)$ & $158(31.6 \%)$ & $128(25.6 \%)$ & $71(14.2 \%)$ & $35(7 \%)$ \\
\hline
\end{tabular}

As shown in Table 3, ASHAs who had studied pre- university education and above expressed more positive attitude compared to those who have studied up to $10^{\text {th }}$ class. No association was found with other variables. 
Table 3: Association between ASHAs attitude towards suicide prevention with demographic variables

\begin{tabular}{|c|c|c|c|c|}
\hline Socio- demographic variable & Below Median & Median and above & $\begin{array}{c}\text { Chi Square } \\
\text { value }\end{array}$ & p- value \\
\hline \multicolumn{5}{|l|}{ Age } \\
\hline - 20-30 Years & 58 & 66 & \multirow{3}{*}{0.909} & \multirow{3}{*}{0.629} \\
\hline - 31-40 Years & 166 & 157 & & \\
\hline - 41-50 Years & 25 & 28 & & \\
\hline \multicolumn{5}{|l|}{ Marital Status } \\
\hline - $\quad$ Married & 249 & 249 & \multirow{2}{*}{1.992} & \multirow{2}{*}{0.158} \\
\hline - Unmarried & 0 & 2 & & \\
\hline \multicolumn{5}{|l|}{ Education } \\
\hline - Higher Primary Education & 9 & 5 & \multirow{3}{*}{8.991} & \multirow{3}{*}{$0.011^{*}$} \\
\hline - Secondary Education & 194 & 172 & & \\
\hline - $\quad$ PUC and Above & 46 & 74 & & \\
\hline \multicolumn{5}{|l|}{ Religion } \\
\hline - $\quad$ Hindu & 248 & 251 & \multirow{2}{*}{1.010} & \multirow{2}{*}{0.315} \\
\hline - Muslim & 1 & 0 & & \\
\hline \multicolumn{5}{|l|}{ Location } \\
\hline - $\quad$ Rural & 248 & 251 & \multirow{2}{*}{1.010} & \multirow{2}{*}{0.315} \\
\hline - Urban & 1 & 0 & & \\
\hline \multicolumn{5}{|l|}{ SES } \\
\hline - $\quad$ Lower Middle Class & 2 & 2 & \multirow{3}{*}{0.059} & \multirow{3}{*}{0.971} \\
\hline - $\quad$ Middle Class & 236 & 239 & & \\
\hline - Upper Middle Class & 11 & 10 & & \\
\hline \multicolumn{5}{|l|}{ Experience } \\
\hline - Less than 2 Years & 52 & 46 & 1.113 & 0.827 \\
\hline - 3-6 Years & 60 & 71 & & \\
\hline - 7-10 Years & 137 & 134 & & \\
\hline
\end{tabular}

$* p<0.05$

\section{Discussion}

Primary health care staff have a long and close contact with the community and are well accepted by local people. They are often the entry point to health services for those in distress. Their knowledge of the community enables them to gather support from family, friends and organizations. ${ }^{10}$

Current research indicates that the prevention of suicide, while feasible, involves a whole series of activities, ranging from provision of the best possible conditions for bringing up our children and young people, through accurate and timely assessment of mental disorders and their effective treatment, to the environmental control of risk factors. Appropriate dissemination of information and awareness-raising are essential elements in the success of suicide prevention. ${ }^{11}$

Repeated suicide attempts point toward health professionals' especially primary health care staffs failure to recognize and respond to the needs of patients with suicide risk and attempt. ${ }^{12}$ Understanding communities' attitudes towards suicide has been proposed as a key to the design and implementation of educational and preventative efforts. ${ }^{13}$

In our study more than $50 \%$ of ASHAs had negative attitude towards suicide prevention. This is in contrast to other studies done by Singh $\mathrm{H}$ et $\mathrm{al}^{9}$ on non-mental health care providers and Anderson, ${ }^{14}$ McLaughlm,,${ }^{15}$ and Nebhinani et $\mathrm{al}^{8}$ on nursing staff where more than $50 \%$ had a positive attitude. One of the reasons for this may be ASHAs not attending any suicide prevention awareness programmes or training. Previous studies have shown that education about suicide and suicide prevention and professional experience impacts the positive attitude. ${ }^{16-20}$ In our study we found no association between professional experience and attitude. This is because since the launch of NRHM and ASHAs recruitment, no training been given specifically regarding suicide. Improper knowledge about suicide, negative attitude toward suicide attempters, incompetence in assessing and managing suicidal risk acts as barriers in management of suicide attempters. ${ }^{21}$

In our study one third of ASHAs were not comfortable on assessing suicide risk, considered suicide prevention as not their responsibility and working with them as not rewarding. It is in contrast to the results of other studies done on non-mental health care providers like doctors, interns, postgraduate medical students and staff nurses ${ }^{9}$ and nursing staff. ${ }^{8}$ This negative attitude may be due to their socio economic background, low educational status and lack of educative programs about suicide compared to other health care staff. Since in India there is scarcity of mental health professionals in effective management of suicide prevention ASHAs need to accept their role in helping suicidal patients.

In our study one third agreed that unemployment and poverty are the main causes of suicide, there is little that an individual can do to prevent it whereas in study by Singh $\mathrm{H}$ et $\mathrm{al}^{9}$ nearly $70 \%$ disagreed. This is because ASHAs without 
scientific knowledge, knowing biological component of suicide tend to think like common man considering only social causes for suicide.

In our study $45 \%$ opined there is no way of knowing who is going to commit suicide. Data from the WHO WMH Surveys ${ }^{11}$ indicate that, known risk factors account for $62.4 \%$ and $80.3 \%$ of the variance in predicting suicide ideation and attempts. That means ASHAs are not aware of the risk factors and early warning signs which largely helps in preventing suicide.

The magnitude of problem of suicide in India is huge, but there is scarcity of mental health professionals in effective management of suicide prevention. Hence, ASHAs can be utilized as a part of multidisciplinary team at various levels in risk assessment and management of suicidal patients. Even previous studies have shown that a brief training program on suicide prevention for frontline general hospital personnel had significant impact on their attitudes and beliefs towards suicide. ${ }^{22,23}$ Hence future similar awareness programmes may help ASHAs to develop insight regarding suicide prevention.

\section{Limitations}

Though our study results show interesting findings it must be seen within its limitations. Attitude toward suicide prevention scale is not adapted for Indian population. Data is collected from ASHAs working in only one district, so findings cannot be generalized.

\section{Conclusion}

Negative attitude is widely prevalent regarding suicide among ASHAs. Less than half of the ASHAs had positive attitude toward working with suicidal patients. Majority of them did not express positive intent to work with suicidal patients and are not aware of risk factors for suicide. Majority opined unemployment and poverty as main underlying factors and were not optimistic about preventive measures.

Future studies should assess various grass root health professionals' attitude to suicide prevention in different populations and settings. The findings of this study have implications for conducting educative workshops for ASHAs for improving their attitudes toward patients with self-harm and to adopt proper clinical strategies to prevent suicide.

\section{Acknowledgment: Nil.}

\section{Conflicts of Interest: Nil.}

\section{References}

1. Lozano R, Naghavi M, Foreman K, Lim S, Shibuya K, Aboyans $\mathrm{V}$ et al. Global and regional mortality from 235 causes of death for 20 age groups in 1990 and 2010: a systematic analysis for the Global Burden of Disease Study 2010. Lancet. 2012;380:2095-2128.

2. Phillips MR, Cheng HG. The changing global face of suicide. Lancet. 2012;379:2318-2319.

3. Preventing suicide: a resource for media professionals, update 2017. Geneva: World Health Organization; 2017 (WHO/MSD/MER/17.5). Licence: CC BY-NC-SA 3.0 IGO.

4. National Health Mission (Home page on the internet). About Accredited Social Health Activist (ASHA). (Updated 2014
Aug 2: cited 2018 Oct 4). Available on

http://nhm.gov.in/communitisation/asha/about-asha.html.

5. Herron J, Ticehurst H, Applebury L, Perry A, Cordingley L. Attitudes toward suicide prevention in front line health staff. Suicide Life Threat Behav. 2001;31:342-347.

6. Brunero S, Smith J, Bates E, Fairbrother G. Health professionals' attitudes towards suicide prevention initiatives. $J$ Psychiatr Ment Health Nurs. 2008;15:588-5894.

7. Appleby L, Moriss R, Gask L, Roland M, Perry B, Lewis A, et al. An educational intervention for front-line health professionals in the assessment and management of suicidal patients (The STORM Project). Psychol Med. 2000;30:805812.

8. Nebhinani N, Mamta, Gaikwad AD, Tamphasana L. Nursing students' attitude toward suicide prevention. Ind Psychiatry $J$. 2013;22(2):114-117.

9. Singh H, Megha N Shalavadi, Thyloth M. A study of attitude towards suicide prevention among non- mental health care providers. Telangana J Psychiatry. 2017:3(1):23-27.

10. World Health Organisation. The Global Burden of Disease: 2004 update. Geneva: WHO: 2008.

11. Nock MK, Borges G, Ono Y. Suicide: Global Perspectives from the WHO World Mental Health Surveys. New York: Cambridge University Press: 2012.

12. Ouzouni C, Nakakis K. Attitudes towards attempted suicide: The development of a measurement tool. Health Sci J. 2009;3:222-231.

13. Domino G, Westlake L, Gibson L. Attitudes toward suicide. A factor analytic approach. J Clin Psychol. 1982;38:257-262.

14. Anderson M. Nurses' attitudes towards suicidal behaviour: A comparative study of community mental health nurses and nurses working in an accident and emergency department. $J$ Adv Nurs. 1997;25:1283-1291.

15. McLaughlin C. Casualty nurses' attitudes to attempted suicide. J Adv Nurs. 1994;20:1111-1118.

16. Samuelsson M, Asberg M, Gustavsson JP. Attitudes of psychiatric nursing personnel towards patients who have attempted suicide. Acta Psychiatr Scand. 1997;95(3):222-230.

17. Gurrister L, Kane RA. How therapists perceive and treat suicidal patients. Community Ment Health J. 1978Spring;14(1):3-13.

18. Huband N, Tantam D. Attitudes to self-injury within a group of mental health staff. Br J Med Psychol. 2000;73Pt 4:495-504.

19. Commons Treloar AJ, Lewis AJ. Professional attitudes towards deliberate self-harm in patients with borderline personality disorder. Aust N Z J Psychiatry. 2008; 42(7):578584.

20. Sun FK, Long A, Boore J. The attitudes of casualty nurses in Taiwan to patients who have attempted suicide. J Clin Nurs. 2007;16(2):255-263.

21. Chan SW, Chien WT, Tso S. Evaluating nurses' knowledge, attitude and competency after an education programme on suicide prevention. Nurs Educ Today. 2009; 29:763-769.

22. Yousuf S, Beh PS, Wong PW. Attitudes towards suicide following an undergraduate suicide prevention module: experience of medical students in Hong Kong. Hong Kong Med J. 2013;19(5):377-385.

23. Berlim MT, Perizzolo J, Lejderman F, Fleck MP, Joiner TE. Does a brief training on suicide prevention among general hospital personnel impact their baseline attitudes towards suicidal behavior?. J Affect Disord. 2007;100(1-3):233-239. 